\title{
PENERAPAN PRINSIP GCG (TRANSPARANSI \& AKUNTABILITAS) DALAM KERANGKA LAPORAN KEUANGAN KELOMPOK PEMODAL 13 DI PONTIANAK TIMUR
}

\author{
Mardiyati (STIE Pontianak) \\ Hijrah Wahyudi (STIE Indonesia Pontianak)
}

\begin{abstract}
Purpose of this research is to know implication of GCG's Principles (Transparency \& Accountability) in Financial Statement's framework of Kelompok Pemodal 13 in Pontianak Timur. This analysis is done by qualitative analysis in order to answer the research. The study conclude that implication of GCG's Principles are important for Kelompok Pemodal 13 in order to construct their Financial Statement's framework based on Standar Akuntansi Keuangan (SAK) and to raise credibility of stakeholders.
\end{abstract}

\section{Keyword: GCG's Principles, Financial Statement's framework, Kelompok Pemodal 13.}

\section{PENDAHULUAN}

Di dalam pelaksanaan Good Corporate Governance (GCG terkandung hubungan antara dewan komisaris, manajemen puncak, dan pemegang saham yang menentukan arah dan kinerja perusahaan. Perwujudan GCG tersebut tidak terlepas dari pelaksanaan prinsip-prinsip dasar yang meliputi: Transaparansi, Akuntabilitas, Responsibilitas, Indenpendensi, serta Kesetaraan dan Kewajaran.

Berfokus pada 2 (dua) prinsip GCG yaitu Transparansi dan Akuntabilitas, maka perusahaan diharuskan mempertanggungjawabkan kinerjanya secara transparan dan wajar, dikelola secara terukur, dan memperhitungkan kepentingan stakeholders. Adapun bentuk pertanggungjawaban kinerja perusahaan dapat ditinjau dari aspek kesehatan keuangan melalui Laporan Keuangan perusahaan yang disampaikan secara periodik.

Di dalam Standar Akuntansi Keuangan (SAK) dinyatakan bahwa laporan keuangan merupakan bagian dari proses pelaporan keuangan yang lengkap biasanya meliputi neraca, laporan laba rugi, laporan perubahan posisi keuangan yang dapat disajikan dalam berbagai cara seperti misalnya: sebagai laporan arus kas, atau laporan arus dana, catatan dan laporan lain serta materi penjelasan yang merupakan bagian integral dari laporan keuangan.

Adapun komponen-komponen laporan keuangan sudah semestinya disesuaikan dengan kebutuhan perusahaan, agar tidak menimbulkan informasi yang keliru bagi para pembaca laporan keuangan yang berkepentingan (stakeholders).
Untuk itu, dibutuhkan analisis pengukuran kebutuhan (need-assesstment) mengenai komponenkomponen apa saja yang ideal untuk dimasukkan ke dalam laporan keuangan dan sebaliknya.

Di Kecamatan Pontianak Timur, Kotamadya Pontianak terdapat 1 (satu) kumpulan masyarakat ekonomi berbasis murni syari'ah yang menyebut diri mereka sebagai Kelompok Pemodal 13. Kegiatan utama kelompok ini adalah:

1. Funding; mengumpulkan dana secara rutin dari para shahibul maal (anggota) dalam bentuk Akad Wadi'ah (Titipan).

2. Lending; menyediakan dana untuk dimanfaatkan oleh masyarakat sekitarnya dalam bentuk Akad Qardh (utang).

Dari 2 (dua) kegiatan utama tersebut, dapat disimpulkan bahwa stakeholders Kelompok Pemodal 13 ini meliputi:

1. Shahibul Maal, yaitu pihak yang menitipkan harta berupa uang tunai.

2. Gharimin, yaitu pihak yang memanfaatkan harta titipan atau uang tunai dari shahhibul maal.

Sebagai bentuk penerapan Prinsip GCG, utamanya Prinsip Transaparansi dan Akuntabilitas, maka sudah seharusnyalah Kelompok Pemodal 13 mempertanggungjawabkan kinerja keuangannya kepada stakeholders dalam bentuk Laporan Keuangan secara periodik yang disusun dengan berlandaskan pada Prinsip Akuntansi Yang Berlaku Umum di Indonesia, dalam hal ini mengacu pada Standar Akuntansi Keuangan. (SAK). Agar laporan keuangan yang disusun dan disampaikan kepada stakeholders memenuhi manfaatnya serta tidak 
mubazir, maka perlu dilakukan pengukuran kebutuhan terkait dengan komponen-komponen dalam laporan keuangan yang sesuai dengan kebutuhan Kelompok Pemodal 13.

\section{Identifikasi dan Perumusan Masalah Penelitian}

Berdasarkan deskripsi tersebut, maka dapat diformulasikan rumusan masalah penelitian sebagai berikut :

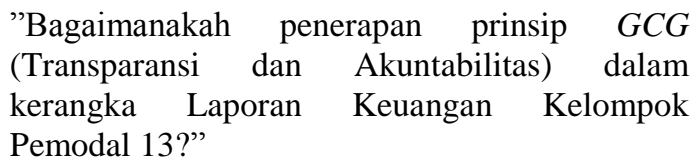

\section{Tujuan Penelitian}

Adapun tujuan dari penelitian ini adalah untuk mengukur kebutuhan komponen-komponen dalam laporan keuangan yang sesuai bagi Kelompok Pemodal 13

\section{Manfaat Penelitian}

Penelitian ini diharapkan bermanfaat :

a. Secara Teoritis; hasil penelitian ini diharapkan bisa menambah pengetahuan dalam penerapan prinsip $G C G$ terutama yang terkait dengan penyusunan kerangka laporan keuangan.

b. Secara Praktis; hasil penelitian ini diharapkan berguna bagi Kelompok Pemodal 13 dalam menentukan menerapkan prinsip $G C G$ terutama yang terkait dengan penyusunan kerangka laporan keuangan.

\section{Teknik Pengumpulan Data}

Data dalam penelitian ini diperoleh melalui :

a. Observasi, yaitu pengumpulan data primer dengan cara mengamati secara sistematis untuk memperoleh informasi tentang fenomena yang diteliti.

b. Studi dokumenter yang dilakukan dengan cara mengkategorisasi (mengklasifikasi), kemudian mempelajari bahan-bahan tertulis yang berhubungan dengan masalah penelitian dan mengambil data atau informasi yang dibutuhkan. Sumbernya bisa berupa dokumen, buku, majalah, koran, dan lain-lain. Data yang diperoleh adalah data sekunder.

Jenis data yang digunakan dalam penelitian ini meliputi :

a. Data Primer, yaitu data yang belum tersedia sehingga untuk menjawab masalah penelitian, data harus diperoleh dari sumber aslinya. b. Data Sekunder, yaitu data yang sudah tersedia atau sudah dikumpulkan untuk suatu tujuan sebelumnya.

\section{Teknik Analisis Data}

Untuk menjawab pertanyaan penelitian digunakan teknik analisis data secara kualitatif yang mengikuti tiga tahapan berikut ini:

A. Persiapan

1. Menyusun rancangan penelitian; penelitian yang akan dilakukan berangkat dari permasalahan dalam lingkup peristiwa yang sedang terus berlangsung dan bisa diamati serta diverifikasi secara nyata pada saat berlangsungnya penelitian. Peristiwa-peristiwa yang diamati dalam konteks kegiatan orang-orang/organisasi.

2. Memilih lokasi Penelitian; sesuai dengan permasalahan yang diangkat dalam penelitian, maka dipilih lokasi penelitian yang digunakan sebagai sumber data.

3. Mengurus perizinan; Mengurus berbagai hal yang diperlukan untuk kelancaran kegiatan penelitian.

4. Menjajagi dan melihat keadaan; proses penjajagan lapangan dan sosialisasi diri dengan keadaan, karena kitalah yang menjadi alat utamanya maka kitalah yang akan menetukan apakah lapangan merasa terganggu atau tidak.

5. Memilih dan memanfaatkan informan; ketika kita menjajagi dan mensosialisasikan diri di lapangan, ada hal penting lainnya yang perlu kita lakukan yaitu menentukan narasumber.

6. Menyiapkan instrumen penelitian; dalam penelitian kualitatif, peneliti adalah ujung tombak sebagai pengumpul data (instrumen). Peneliti terjun secara langsung ke lapangan untuk mengumpulkan sejumlah informasi yang dibutuhkan. Dalam rangka kepentingan pengumpulan data, teknik yang digunakan dapat berupa kegiatan observasi, wawancara dan studi dokumentasi.

B. Lapangan

1. Memahami dan memasuki lapangan; memahami latar penelitian; latar terbuka; dimana secara terbuka orang berinteraksi sehingga peneliti hanya mengamati, latar tertutup dimana peneliti berinteraksi secara langsung dengan orang.

2. Penampilan, Menyesuaikan penampilan dengan kebiasaan, adat, tata cara, dan budaya latar penelitian. 
3. Pengenalan hubungan peneliti di lapangan, bertindak netral dengan peran serta dalam kegiatan dan hubungan akrab dengan subjek.

4. Jumlah waktu studi, pembatasan waktu melalui keterpenuhan informasi yang dibutuhkan.

5. Aktif dalam kegiatan (pengumpulan data); peneliti merupakan instrumen utama dalam pengumpulan data, jadi peneliti harus berperanaktif dalam pengumpulan sumber

C. Pengolahan Data

1. Analisis Data; melakukan analisis terhadap data yang telah didapatkan, peneliti dalam hal ini bisa melakukan interpretasi dari data yang didapatkan dilapangan.

2. Mengambil Kesimpulan dan Verifikasi; dari kegiatan-kegiatan sebelumnya, langkah selanjutnya adalah menyimpulkan dan melakukan verifikasi atau kritik sumber apakah data tersebut valid atau tidak.

3. Narasi Hasil Analisis; langkah terakhir adalah pelaporan hasil penelitian dalam bentuk tulisan dan biasanya pendekatan kualitatif lebih cenderung menggunakan metode deskriptifanalitis.

\section{TINJAUAN PUSTAKA}

\section{Hal Ihwal Good Corporate Governance}

Secara umum istilah good corporate governance merupakan sistem pengendalian dan pengaturan perusahaan yang dapat dilihat dari mekanisme hubungan antara berbagai pihak yang mengurus perusahaan (hard definition), maupun ditinjau dari "nilai-nilai" yang terkandung dari mekanisme pengelolaan itu sendiri (soft defnition). (Sumber: www.bpkp.go.id)

$$
\text { Menurut Ariyoto (dalam Majalah }
$$

Manajemen Usahawan, 2000), dikenal ada 3 (tiga) model good corporate governance, yaitu:

1. Principal agents model, atau dikenal dengan agency theory, dimana korporasi dikelola untuk memberikan win-win solution bagi pemegang saham sebagai pemilik di satu pihak, dan manajer sebagai agen dilain pihak. Dalam model ini, diasumsikan bahwa kondisi corporate governance suatu perusahaan akan direfleksikan secara baik dalam bentuk sentiman pasar.
2. The myopic Market Model, masih memfokuskan perhatian kepentingankepentingan pemegang saham dan manajer, dimana sentiment pasar lebih banyak dipengaruhi oleh faktor-faktor lain diluar corporate governance. Oleh karena itu, principals dan agent lebih berorientasi pad keuntungan jangka pendek.

3. Stakeholder Model, yang memperhatikan kepentingan pihakpihak yang terkait dengan korporasi secara luas. Artinya, dalam mencapai tingkat pengembalian yang menguntungkan bagi pemegang saham, manajer harus memperlihatkan batasanbatasan yang timbul dalam lingkungan dimana mereka beroperasi, diantaranya masalah etika dan moral, hukum, kebijakan pemerintah, lingkungan hidup, sosial, budaya, politik dan ekonomi.

Amir (2011) menyatakan bahwa prinsipprinsip Good Corporate Governance meliputi :

1. Transparansi, yaitu keterbukaan dalam melaksanakan proses pengambilan keputusan dan keterbukaan dalam mengemukaan informasi materiil dan relevan mengenai perusahaan.

2. Kemandirian, yaitu suatu keadaan dimana perusahaan dikelola secara professional, tanpa benturan kepentingan dan pengaruh/tekanan dari manapun yang tidak sesuai peraturan perundangan yang berlaku dan prinsipprinsip koorporasi yang sehat.

3. Akuntabilitas, yaitu kejelasan fungsi kejelasan dan pertanggungjawaban organ sehingga pengelolaan perusahaan secara efektif.

4. Pertanggungjawaban, yaitu kesuaian dalam pengelolaan perusahaan terhadap peraturan perundangan yang berlaku dan prinsip korporasi yang sehat.

5. Kewajaran, yaitu keadilan dan kesetaraan dalam memenuhi hak-hak stakeholders yang timbul berdasarkan perjanjian dan perundangan yang berlaku. 


\section{Pengertian Laporan Keuangan}

Harahap (2006) menyatakan bahwa laporan keuangan adalah laporan yang menggambarkan kondisi keuangan dan hasil usaha suatu perusahan pada saat tertentu atau jangka waktu tertentu.

Baridwan (2004) berpendapat bahwa laporan keuangan merupakan ringkasan dari suatu proses pencatatan, merupakan suatu ringkasan dari transaksi-transaksi keuangan yang terjadi selama tahun buku yang bersangkutan.

Menurut Machfoedz dan Mahmudi (2008) laporan keuangan adalah hasil akhir dari proses akuntansi. Proses akuntansi dimulai dari bukti transaksi, kemudian dicatat dalam harian yang disebut jurnal, kemudian secara periodik dari jurnal dikelompokkan ke dalam buku besar sesuai dengan transaksinya, dan tahap terakhir dan proses akuntansi adalah penyusunan laporan keuangan.

\section{Pengguna Laporan Keuangan}

Menurut Standar Akuntansi Keuangan yang dirilis oleh Ikatan Akuntan Indonesia (2002), pengguna laporan keuangan berikut diantaranya:

1. Manajer; Laporan keuangan digunakan untuk mengambil keputusan kebijakan dalam operasi perusahaan bagi seorang manajer. Baik itu keputusan keputusan strategis perusahaan dan rencana rencana yang akan dijalankan untuk memaksimalkan keuntungan.

2. Investor; seorang investor atau penanam modal dalam perusahaan juga dengan para penasihatnya berkepentingan mengetahui hasil dari investasi mereka. Juga dengan segala risiko yang melekat dan mungkin akan ditimbulkan dari investasi yang telah mereka keluarkan untuk perusahaan. Kepentingannya sangat sederhana, mendapatkan laba. Dan juga memutuskan apakah mereka tetap akan menjadi investor, mengurangi jumlah kepemilikan saham atau bahkan menarik diri (menjual saham) dari perusahaan. Investor juga tertarik dengan informasi mengenai kemampuan perusahaan dalam membayar deviden untuk mereka.

3. Karyawan; kelompok yang mewakili suara mereka juga membutuhkan informasi mengenai tingkat profitabilitas dan tingkat kestabilitas perusahaan. Karyawan ingin tahu informasi untuk mengetahui kemampuan perusahaannya dalam memberikan tingkat upah atau gaji mereka. Karyawan juga ingin tahu tentang informasi kesempatan kerja dan informasi manfaat pensiun.

4. Kreditur; pemberi pinjaman atau kreditur ingin tahu apakah pinjaman yang telah mereka berikan dan juga bunganya bisa dibayarkan ketika sudah jatuh tempo nanti. Pemberi pinjaman ini bisa Bank atau lembaga bukan Bank atau individu dan entitas lainnya.

5. Pemasok (rekanan) dan kreditor usaha; Pemasok atau rekanan seperti pemasok bahan baku bagi perusahaan menggunakan laporan keuangan untuk mengambil keputusan apakah jumlah nominal yang terutang akan terbayar saat tiba jatuh tempo nanti. Kreditor usaha memerlukan informasi untuk kepentingan apabila perusahaan yang diutangi adalah pelanggan utama perusahaan pemasok, dan kelangsungan hidup pemasok ini tergantung pada mereka.

6. Pemerintah; Kepentingan pemerintah dominan berkaitan dengan pajak, Pemerintah butuh laporan keuangan perusahaan untuk mengatur aktivitasnya, menyusun data data statistik untuk kepentingan negara tentunya.Dan yang utama adalah menetapkan kebijakan pajaknya. Akuntansi yang digunakan di sini berbeda antara laporan akuntansi keuangan perusahaan, biasa disebut dengan Akuntansi Perpajakan

7. Pelanggan; jika suatu pelanggan terlibat dalam suatu perjanjian jangka panjang dengan perusahaan, mereka juga membutuhkan informasi tentang kelangsungan hidup perusahaan.

8. Masyarakat; sebuah perusahaan bisa memberi pengaruh terhadap masyarakat dalam beberapa cara, contohnya jumlah orang yang menjadi pekerja di perusahaan, perlindungan untuk penanam modal dalam negeri.Informasi keuangan perusahaan bisa membantu masyarakat menyediakan info atau trend perkembangan terakhir tentang rangkaian aktivitas perusahaan. 
Manfaat Laporan Keuangan

Berdasarkan Standar Akuntansi Keuangan yang dirilis oleh Ikatan Akuntan Indonesia (2002):

1. Menyediakan informasi tentang posisi keuangan sesuai hakikat akuntansi, kinerja, dan perubahan posisi keuangan suatu perusahaan yang berhubungan dengan pengambilan keputusan ekonomi.

2. Memenuhi kebutuhan sebagian besar pemakai yang berpengaruh terhadap transaksi keuangan dan terkadang juga bisa menyajikan informasi nonkeuangan.

3. Menunjukkan kinerja manajemen (stewardship) atau pertanggungjawaban manajemen terhadap sumber daya yang dipercayakan kepada pihak manajemen. Pengguna laporan keuangan (pemiliki perusahaan dan direksi) yang menilai kinerja atau pertanggungjawaban manajemen sehingga pemilik modal bisa membuat keputusan ekonomi untuk menahan atau menjual investasi di dalam perusahaan. Keputusan yang dibuat biasanya juga dilakukan untuk mengangkat kembali atau mengganti manajemen.

4. Menyediakan informasi tentang jenis dan jumlah aktiva (harta) yang dimiliki perusahaan pada masa kini (dalam satu periode) sehingga pihak internal perusahaan bisa melakukan keputusan untuk pembaharuan aset atau mempertahankan yang ada.

5. Menyediakan informasi tentang jenis dan jumlah kewajiban serta modal yang dimiliki perusahaan pada masa kini. Jika modal dirasa tidak cukup maka pihak internal harus melakukan berbagai upaya agar banyak investor yang menanamkan modal di perusahaan tersebut.

6. Menyediakan informasi tentang jenis dan jumlah pendapatan yang diperoleh pada suatu periode sehingga jika terjadi penurunan pendapatan maka harus dilakukan peningkatan promosi agar penjualan semakin meningkat.

7. Menyediakan informasi tentang jumlah biaya dan jenis biaya perusahaan dalam suatu periode tertentu sehingga perusahaan bisa mengurangi biaya atau penghematan berbagai sumber daya.
8. Menyediakan informasi tentang perubahan-perubahan akibat ketersediaan dan pemakaian aktiva (macam macam harta dalam akuntansi), pasiva, dan modal perusahaan sehingga pihak manajemen bisa menetapkan berbagai kebijakan yang bermanfaat bagi perusahaan.

9. Menyediakan informasi tentang kinerja manajemen perusahaan dan catatan atas laporan keuangan dalam suatu periode.

\section{HASIL PENELITIAN}

\section{Need-assestments komponen-komponen Laporan Keuangan}

1. Bila diukur dari orientasi usaha, Kelompok Pemodal 13 termasuk usaha yang berorientasi nirlaba (non-profit oriented), oleh karena itu di dalam Laporan Keuangan tidak dicantumkan informasi mengenai kondisi Laba atau Rugi.

2. Bila diukur dari ada atau tidaknya pendapatan dan biaya dari kegiatan normal usaha, maka di dalam Kelompok Pemodal 13 tidak terdapat pendapatan (karena tidak terdapat transaksi jual beli produk baik barang dan atau jasa) maupun biaya dari kegiatan normal usaha. Hal ini bisa terjadi karena kegiatan utama adalah transaksi utang-piutang berbasis syari'ah (qardh). Akibatnya adalah tidak dibutuhkan penyusunan dan pelaporan hasil usaha yang biasanya dituangkan dalam Laporan Laba/Rugi.

3. Laporan Keuangan yang harus disediakan oleh Kelompok Pemodal 13 sekurangkurangnya terdiri atas Neraca, dan Laporan Perubahan Modal-Titipan

\section{Need-assestments komponen rekening-rekening dalam Neraca}

Berdasarkan analisis pengukuran kebutuhan, dapat dirumuskan komponen rekening-rekening yang ideal dicantumkan di dalam Neraca Kelompok Pemodal 13, yaitu:

\section{Aktiva:}

1. Kas, yaitu rekening yang digunakan untuk mencatat sumber dana yang berasal titipan shahibul maal. Digunakan juga untuk mencatat penggunaan dana oleh gharimin. 
Transaksi ini terjadi dengan frekuensi rutin.

2. Piutang, yaitu rekening yang digunakan untuk mencatat mutasi piutang (baik pertambahan maupun pelunasan). Transaksi ini terjadi dengan frekuensi rutin.

3. Mudharabah, yaitu rekening yang digunakan untuk mencatat transaksi dengan akad mudharabah (investasi dengan bagi hasil). Transaksi ini terjadi dengan frekuensi jarang, tetapi tetap harus dilaporkan dalam Neraca.

\section{Pasiva (Utang, dan Modal)}

1. Utang-Shahibul Maal, yaitu rekening yang digunakan untuk mencatat transaksi utang Kelompok Pemodal 13 kepada shahibul maal ketika terjadi kekurangan dana likuid sementara dana yang dibutuhkan untuk gharimin jumlahnya lebih banyak. Transaksi ini terjadi dengan frekuensi jarang.

2. Modal-Infak, yaitu rekening yang digunakan untuk mencatat transaksi penambahan modal yang dananya berasal dari infak baik pihak internal maupun eksternal Kelompok Pemodal 13. Transaksi ini terjadi dengan frekuensi cukup.

3. Modal-Titipan Diterima Dimuka, yaitu rekening yang digunakan untuk mencatat transaksi dana titipan shahibul maal yang melakukan penitipan untuk lebih dari 1 (satu) periode akuntansi. Transaksi ini terjadi dengan frekuensi rutin.

4. Modal-Titipan, yaitu rekening yang digunakan untuk mencatat transaksi penambahan titipan modal yang berasal dari titipan shahibul maal, serta penarikan titipan dari shahibul maal (baik itu penarikan sebagian maupun penarikan keseluruhan ketika shahibul maal menyatakan berhenti sebagai shahibul maal). Transaksi ini terjadi dengan frekuensi rutin.

Dari hasil pengukuran kebutuhan tersebut dapat diformulasikan format Neraca Kelompok Pemodal 13 sebagai berikut:

Kelompok Pemodal 13

Neraca

Periode 31 bulan...tahun...

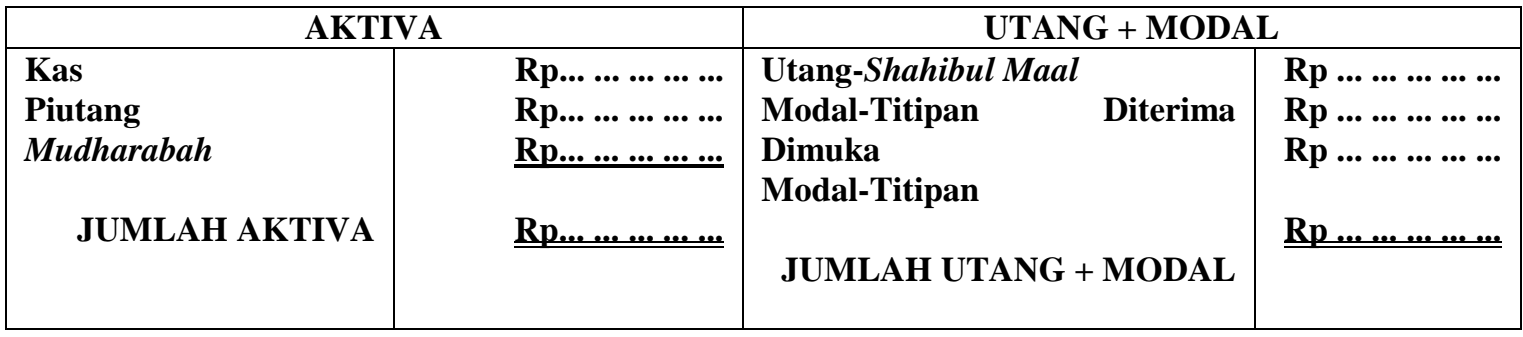

Need-assestments komponen-komponen dalam Laporan Perubahan Modal-Titipan

Berdasarkan analisis pengukuran kebutuhan, dapat dirumuskan komponen-komponen yang ideal dicantumkan di dalam Laporan Perubahan Modal-Titipan Kelompok Pemodal 13, yaitu:

1. Modal-Titipan per 01 periode berjalan, yaitu akumulasi modal titipan yang bersumber dari titipan periode-periode sebelumnya.
2. Penambahan Modal-Titipan, yaitu penambahan titipan pada periode berjalan.

3. Penarikan Modal-Titipan, yaitu pengurangan titipan pada periode berjalan.

4. Modal-Titipan per 31 periode berjalan, yaitu akumulasi modal titipa yang bersumber dari titipan periode sebelumnya sampai dengan periode berjalan. 
Dari hasil pengukuran kebutuhan tersebut

Perubahan Modal-Titipan Kelompok Pemodal dapat diformulasikan format Laporan

13 sebagai berikut:

\section{Kelompok Pemodal 13 \\ Laporan Perubahan Modal-Titipan \\ Periode 31 bulan...tahun...}

Modal-Titipan per 01 bulan ... tahun ...

Mutasi:

\begin{tabular}{|c|c|}
\hline Penambahan & Rp ... ... ..... \\
\hline $\begin{array}{l}\text { Penarikan } \\
\text { Jumlah Mutasi }\end{array}$ & $\underline{\operatorname{Rp} \ldots \ldots \ldots}$ \\
\hline
\end{tabular}

Modal-Titipan per 31 bulan ... tahun ...
$\mathbf{R p} \ldots \ldots \ldots$

$\underline{\mathrm{Rp} \ldots \ldots \ldots \ldots}$

\section{KESIMPULAN DAN SARAN}

\section{Kesimpulan}

Dari penelitian ini dapat disimpulkan bahwa:

1. Penerapan Prinsip-prinsip Good

Corporate Governance mutlak

dijalankan oleh setiap perusahaan

baik yang berorientasi laba maupun yang tidak berorientasi laba, sebagai bentuk pertanggujawaban manajemen kepada stakeholders, termasuk salah satunya adalah Kelompok Pemodal 13 yang tidak berorientasi laba.

2. Dalam penyusunan kerangka Laporan Keuangan Kelompok Pemodal 13 haruslah berdasarkan need assestments agar diperoleh kerangka Laporan Keuangan yang ideal sebagai media untuk mempertanggungjawabkan kinerja keuangannya.

\section{Saran}

Adapun saran yang dapat diberikan peneliti untuk Kelompok Pemodal 13 sebagai berikut:

1. Sebaiknya selalu memegang teguh dan menerapkan Prinsip-prinsip Good Corporate Governance agar kepercayaan dari stakeholders dapat ditingkatkan.

2. Sebaiknya menerapkan secara konsisten dan kontinyu terhadap kerangka Laporan Keuangan yang sudah dirumuskan, dengan tujuan menjaga dan mempertahankan kualitas Laporan Keuangan.

\section{DAFTAR PUSTAKA}

www.bpkp.go.id

Ariyoto, 2000, Majalah Manajemen Usahawan, Penerbit Lembaga Manajemen FEUI, Jakarta.

M Taufik Amir, 2011, Manajemen Strategik: Konsep dan Aplikasi, Penerbit PT RajaGrafindo Persada, Jakarta.

Sofyan Syafri Harahap, 2006, Analisis Krtitis atas Laporan Keuangan, Penerbit PT RajaGrafindo Persada, Jakarta.

Zaki Baridwan, 2004, Intermediate Accounting, Edisi Kedelapan, BPFE, Yogyakarta.

Mas’ud Machfoedz dan Mahmudi, 2008, Materi Pokok Akuntansi Manajemen, Universitas Terbuka, Jakarta.

Ikatan Akuntan Indonesia, 2002, Standar Akuntansi Keuangan, Salemba Empat, Jakarta. 